\title{
A desktop evaluation of the environmental and economic performance of model dairy farming systems within four New Zealand catchments
}

\author{
R.M. MONAGHAN ${ }^{1}$, D. SMEATON², M.G. HYSLOP ${ }^{3}$, D.R. STEVENS ${ }^{1}$, C.A.M. DE KLEIN ${ }^{1}$, L.C. SMITH ${ }^{4}$, \\ J.J. DREWRY ${ }^{1}$ and B.S. THORROLD ${ }^{5}$ \\ ${ }^{1}$ AgResearch, Invermay Agricultural Centre, PB 50034, Mosgiel \\ ${ }^{2}$ AgResearch, Ruakura Research Centre, PB 3123, Hamilton \\ ${ }^{3}$ Heinz-Watties Ltd, P.O. Box 16083, Christchurch \\ ${ }^{4}$ AgResearch, Woodlands Research Station, R.D. 1, Invercargill \\ ${ }^{5}$ Dexcel, PB 3221, Hamilton \\ ross.monaghan@agresearch.co.nz
}

\begin{abstract}
The environmental and economic performances of low, medium and high input dairy farming systems were evaluated for model farms within catchments in Waikato, Taranaki Canterbury and Southland. These four catchments, predominantly under dairy landuse, are part of a long term systems study of farm productivity and catchment-specific environmental issues. Within each catchment, environmental and economic performance indicators were derived for model farms by using the farm systems modelling tool UDDER and the OVERSEER ${ }^{\mathrm{TM}}$ nutrient budgeting programme. Our analyses indicated that high input systems, currently defined as farms within the top quartile of farm inputs, either as imported feed or fertiliser nitrogen $(\mathrm{N})$, were often the least profitable, as defined by Earnings Before Interest and Tax (EBIT). These high-input systems consistently had the greatest environmental emissions of $\mathrm{N}$ and greenhouse gases, and the greatest energy consumption, on a per hectare and a per $\mathrm{kg}$ milksolids basis. The most profitable farm input system depended on payout and the catchment under study. Evaluation of the whole-farm system using these modelling tools demonstrated the relatively large contribution that stock wintering made to $\mathrm{N}$ emissions from farms within the two South Island catchments. Where reductions in $\mathrm{N}$ losses are sought, it would seem prudent to initially target mitigations at this part of the farm system.
\end{abstract}

Keywords: dairy farming, environmental emissions, farm systems modelling, OVERSEER ${ }^{\mathrm{TM}}$ nutrient budgets, UDDER farm systems tool

\section{Introduction}

Commenced in 2001, the Best Practice Dairying Catchments for Sustainable Growth Project has the aim of integrating environmentally sustainable practices into dairy farming, against the background of a rapidly expanding South Island dairy industry, and the industry's policy of increasing farm business productivity. Coupled with this expansion and intensification has been a growing concern about the impacts of intensive land use on soil and water quality. This concern has been most apparent in many South Island regions that have seen a rapid shift from relatively low intensity dry-stock farming to higher intensity dairying. The initial phases of the project focused on characterizing the physical resources and farming systems within each of the catchments. This allowed us to benchmark the current status of these resources and identify obvious links between landuse practice and resource status. Farmer feedback at Discussion and Resource Care Group meetings has also identified the range of challenges and issues facing land managers, and provided some direction of how future farming systems may evolve in response to these challenges. A recurring debate at these meetings has been the merits or otherwise of low- versus medium- versus high-input dairy production systems. The comparative advantages of each of these systems have been questioned from both economic and environmental standpoints.

There are currently few tools available for predicting how dairy farm systems will respond to management changes from environmental and economic perspectives. Those tools that are available are typically applied in isolation, with the net result that a double bottom line analysis (environmental and economic) is seldom considered. Given this, our challenge was to develop a conceptual framework that could evaluate both farm productivity issues and the wider environmental impacts of future dairy farm systems. To achieve this goal, the farm systems tool UDDER and the OVERSEER ${ }^{\mathrm{TM}}$ nutrient budgets model were applied in tandem to case study farms within each of the catchments. Expert local knowledge, derived from farm surveys and feedback from farm discussion groups, was used to refine and validate the simulations developed using these modelling tools. Model outputs of farm production, profitability and emissions to water and air were combined to provide a more complete picture of the impacts of low-, medium- and high-input production systems. 
Table 1 Some catchment and dairy farm characteristics.

\begin{tabular}{|c|c|c|c|c|c|}
\hline \multicolumn{2}{|l|}{ Attribute } & Toenepi & Waiokura & Waikakahi & Bog Burn \\
\hline \multicolumn{6}{|c|}{ Catchment characteristics } \\
\hline \multicolumn{2}{|c|}{ Rainfall (mm) } & 1200 & 1400 & 540 & 921 \\
\hline \multicolumn{2}{|c|}{ Mean annual temp $\left({ }^{\circ} \mathrm{C}\right)$} & 13.3 & 12.7 & 10.7 & 10.2 \\
\hline \multicolumn{2}{|c|}{ Topography } & Rolling & Flat & Flat & Flat \\
\hline \multicolumn{2}{|l|}{ Major soil type } & Kereone & Manaia & Eyre & Pukemutu \\
\hline $\begin{array}{l}\text { Area occupied by: } \\
\text { (ha) }\end{array}$ & $\begin{array}{l}\text { Dairy } \\
\text { Dairy runoff } \\
\text { Dry stock } \\
\text { Cropping } \\
\text { Forestry }\end{array}$ & $\begin{array}{c}1008 \\
280 \\
264 \\
0 \\
0\end{array}$ & $\begin{array}{c}2,281 \\
52 \\
19 \\
0 \\
\underline{0}\end{array}$ & $\begin{array}{c}2,172 \\
377 \\
1,552 \\
0 \\
0\end{array}$ & $\begin{array}{c}665 \\
242 \\
818 \\
12 \\
737 \\
\end{array}$ \\
\hline \multicolumn{2}{|c|}{ Total catchment area (ha) } & 1,552 & 2,352 & $4, \overline{100}$ & $2 \overline{2,474}$ \\
\hline \multicolumn{2}{|c|}{ Stream lengths $(\mathrm{km})$} & 39.4 & 75.3 & nd & 43.4 \\
\hline \multicolumn{6}{|c|}{ Dairy farm features } \\
\hline \multicolumn{2}{|l|}{ Irrigation (mm/year) } & nil & nil & 810 & nil \\
\hline \multicolumn{2}{|c|}{ Effluent management } & $\begin{array}{l}\text { Ponds \& } \\
\text { Spray }\end{array}$ & $\begin{array}{l}\text { Ponds \& } \\
\text { Spray }\end{array}$ & Spray & Spray \\
\hline \multicolumn{2}{|c|}{ Main type of supplement } & $\begin{array}{l}\text { Maize } \\
\text { silage }\end{array}$ & $\begin{array}{l}\text { Maize } \\
\text { silage }\end{array}$ & $\begin{array}{l}\text { Pasture } \\
\text { silage }\end{array}$ & $\begin{array}{l}\text { Cereal } \\
\text { silage }\end{array}$ \\
\hline
\end{tabular}

Figure 1 Schematic representation of evaluation process.

Pasture growth \& quality monitoring

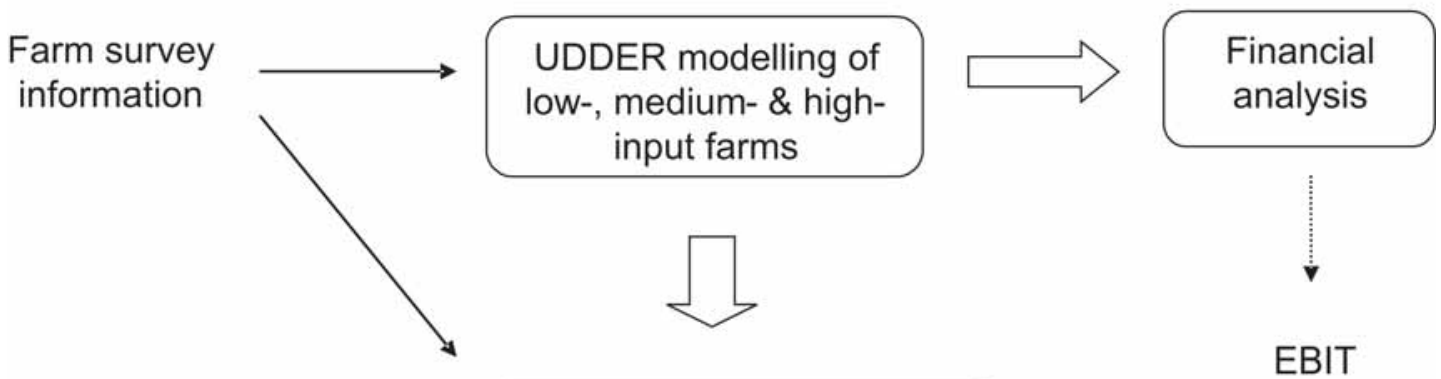

Soil survey information

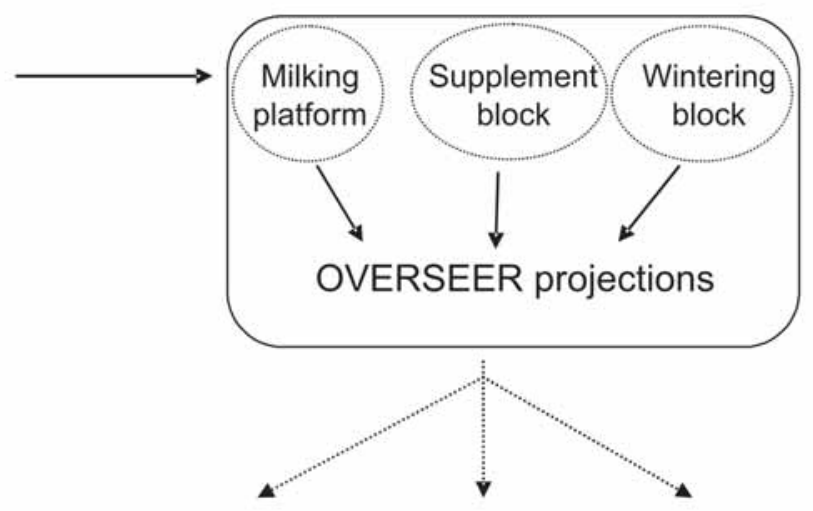




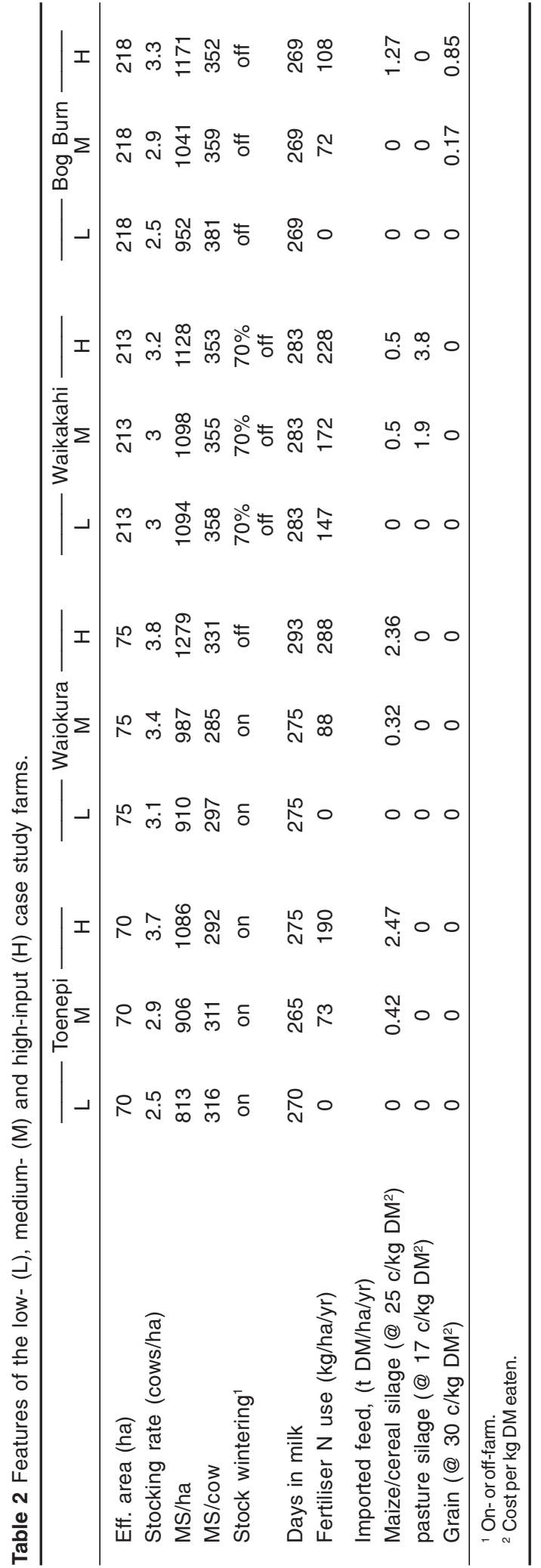

\section{Methodology}

Our approach was to describe the environmental and financial performance of 3 case study dairy farms of contrasting inputs within each of the 4 catchments. These case study farms were derived from detailed surveys of all dairy farms within each catchment: $21,17,11$ and 7 farms within the Toenepi (Waikato), Waiokura (Taranaki), Waikakahi (South Canterbury) and Bog Burn (Southland) catchments, respectively. Some features of the catchments are shown in Table 1. Surveyed farms were ranked according to the amount of additional feed sourced onto the farm either as imported supplement or as $\mathrm{N}$-fertilised pasture. Based on this ranking procedure, farms falling into the lower, middle and upper quartiles of surveyed farms were defined as low-, medium- and high-input farms, respectively. Some features of these model farms are shown in Table 2. In the case of the Waikakahi catchment, all of the farms surveyed used a significant amount of fertiliser $\mathrm{N}$. As a result, farms within this catchment categorised as 'low-input' were relatively similar to 'medium-input' farms, and thus differed from 'low-input' farms in other catchments.

A sequential (and iterative) modelling approach was used to characterise the performance of the case study farms. Farm production and economic performance was evaluated using the UDDER model (Larcombe 1999) and a spreadsheet-based farm financial model, respectively. Summary farm information and output from these models, combined with soil information collected from a biennial survey of 20 transects within each catchment, was then used as input to the OVERSEER ${ }^{\text {TM }}$ nutrient budgeting model (Wheeler et al. 2003) to evaluate farm environmental performance. This output was then aggregated with estimates of environmental emissions from off-farm operations, such as winter grazing or supplement production, to determine the total impact from the dairy farming system under consideration. A schematic diagram of the components and systems approach considered in our analyses is shown in Figure 1. Energy flows were calculated for each part of the dairy system using the approach described by de Klein et al. (2002) and Wells (2001).

Economic analysis of the case study farms was done using a full farm budget. Costs of inputs and expenses were based on data from the MAF Farm monitoring report (Ministry of Agriculture and Forestry 2003) and the Dexcel economic survey (Dexcel 2003). Outputs from the farm included milk, bobby calves and cull cows. Extra inputs such as off-farm grazing and bought-in supplements were valued at market rates, with the milking platform being considered a stand-alone business to remove the complication of calculating net worth of runoffs owned by dairy farmers. Profit was expressed as Earnings Before Interest and Tax (EBIT). Profitability 
Figure 2 Monthly pasture growth rates recorded in the (A) Toenepi, (B) Waiokura, (C) Waikakahi, and (D) Bog Burn catchments. Data presented are mean values for 2 years of pasture monitoring.
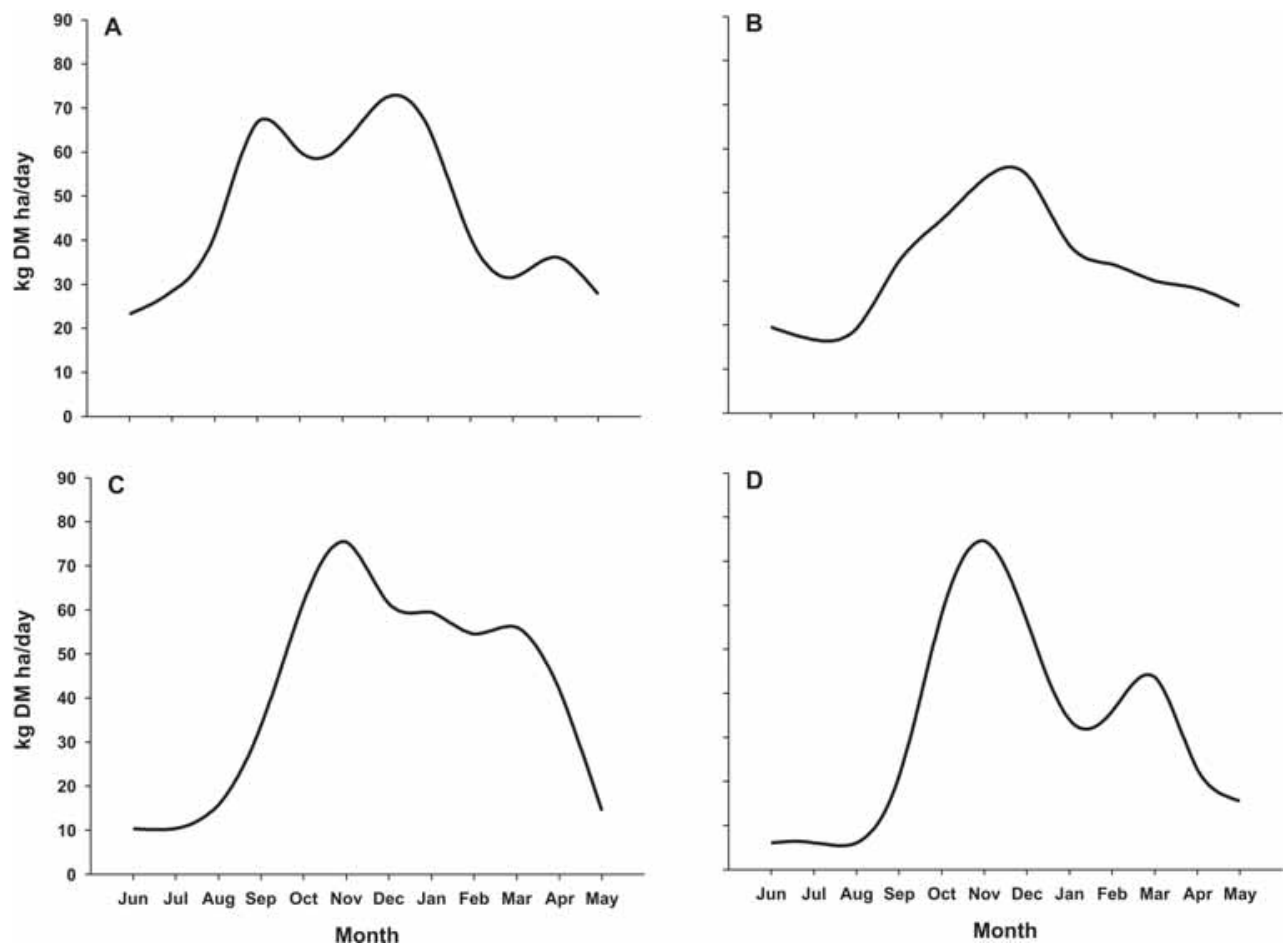

Figure 3 Monthly pasture ME values recorded in the 4 catchments. Data presented are mean values for 2 years of pasture monitoring.

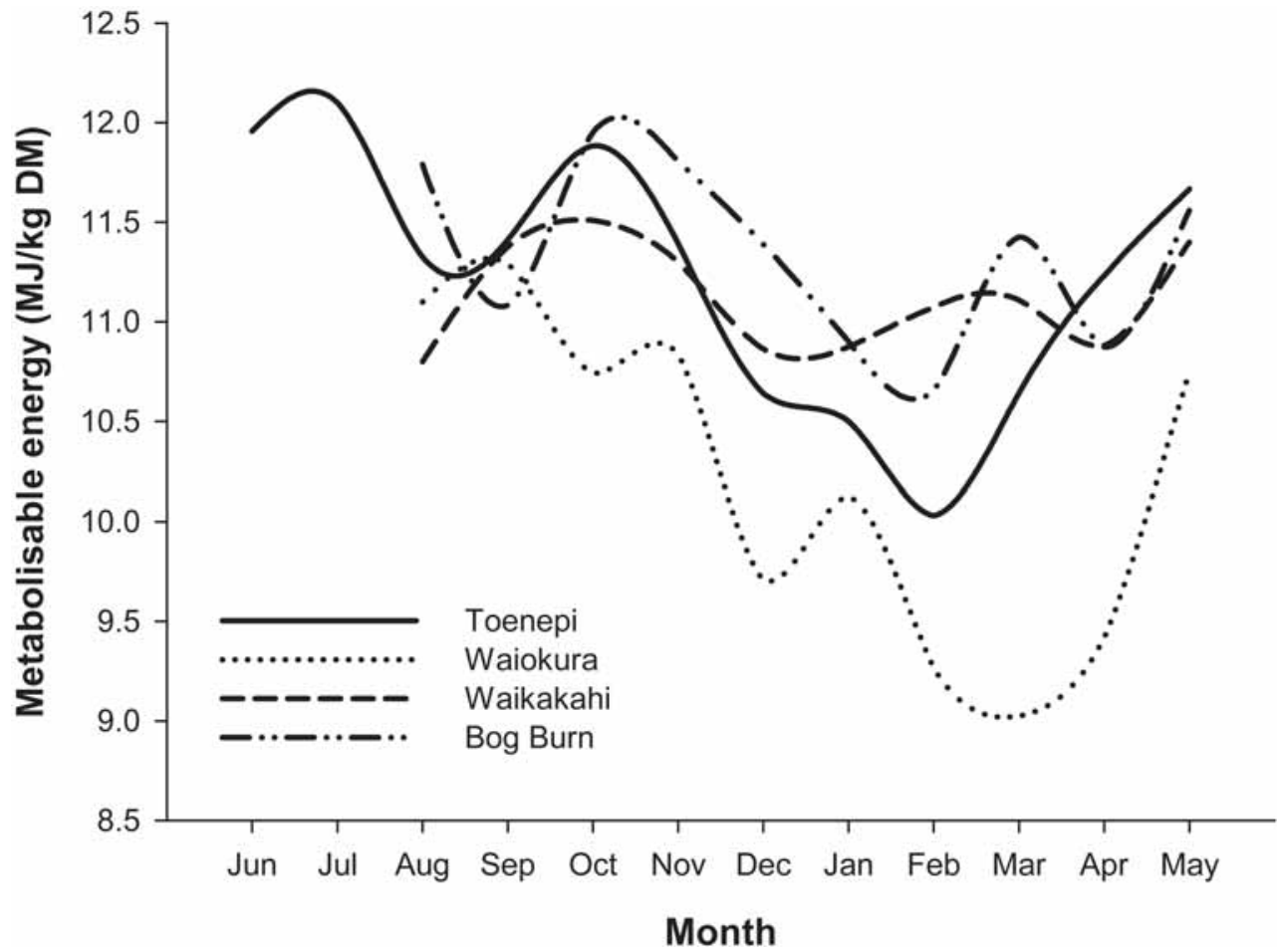



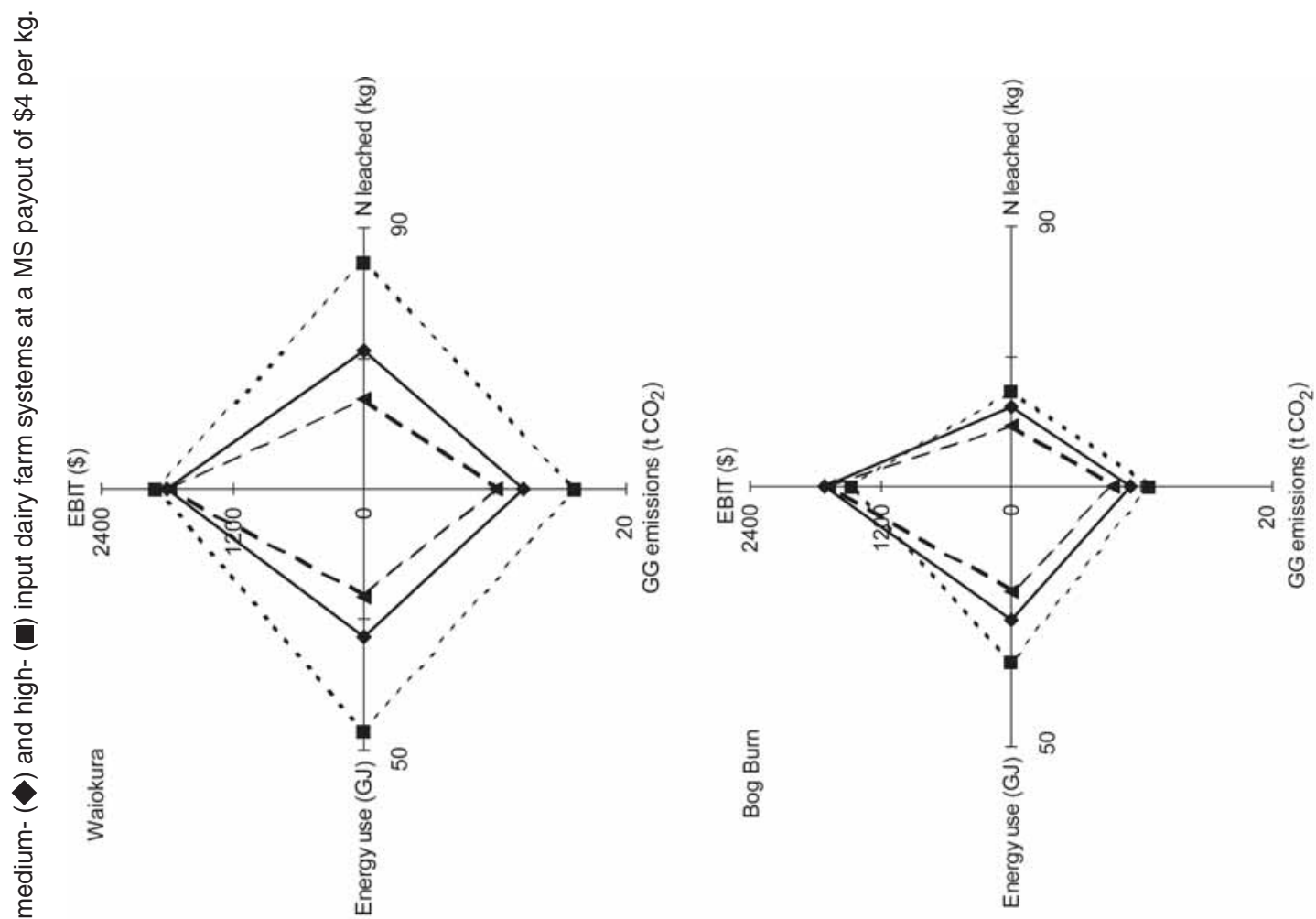

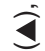

흐
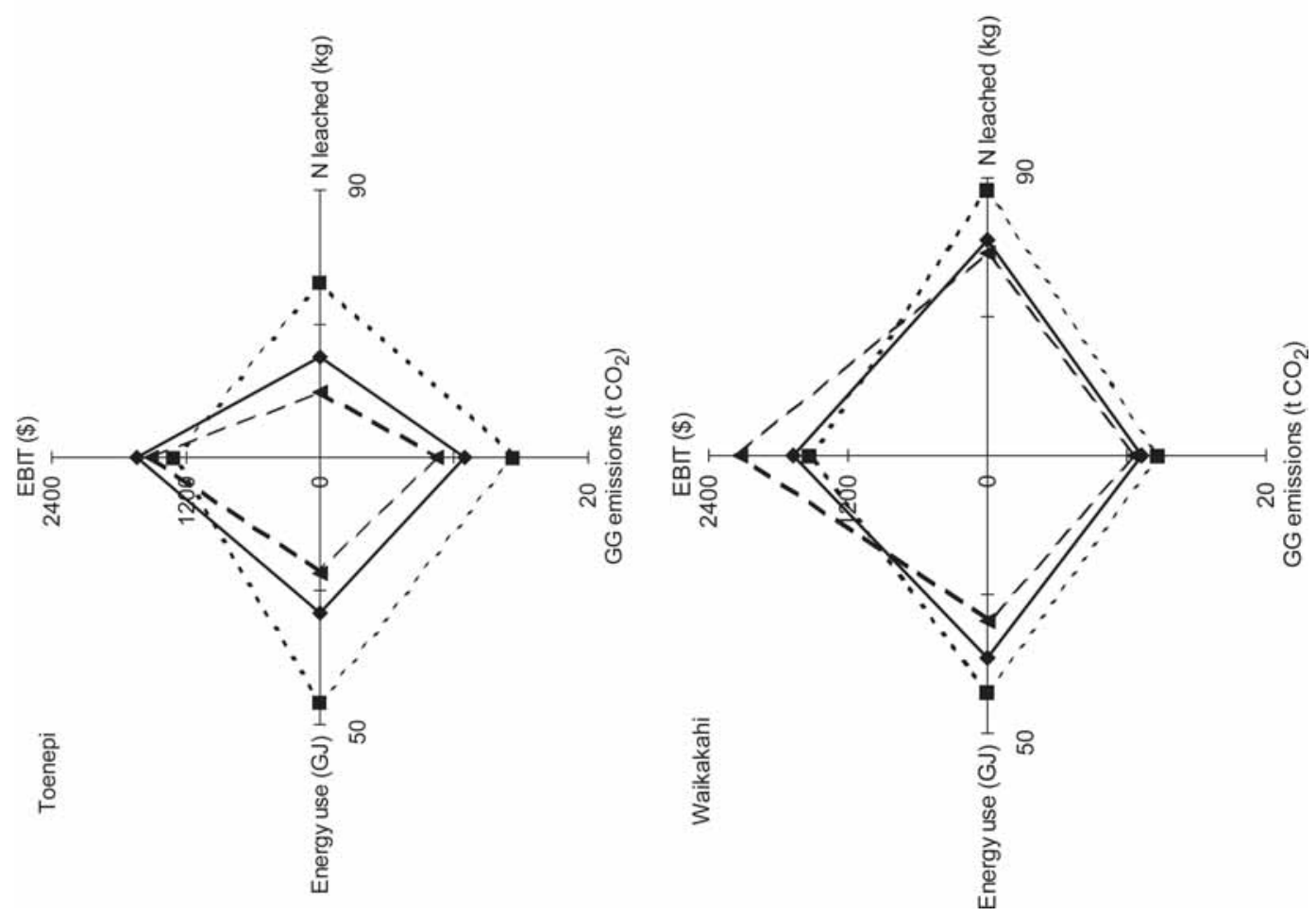

녹 
analyses were performed at payouts ranging from $\$ 3$ to $\$ 5.50$ to assess the sensitivity of each system to fluctuations in payout values. EBIT values were adjusted to account for the fertiliser value of nutrients imported onto medium- and high-input farms via supplements.

Pasture quantity and quality information were key inputs required for running and benchmarking the UDDER model within each catchment. Field measurements were commenced during summer 2002 and continued until the completion of the project in October 2004. Within each catchment, 2 paddocks on each of 2 farms were selected for routine monitoring of pasture growth rates. Pasture growth rates were measured using the "difference" method described by Davis et al. (1999) and Lynch (1966), using 2 pasture cages $2 \mathrm{~m}$ long $\mathrm{x} 1.5 \mathrm{~m}$ wide randomly positioned within each paddock. This method uses a rising plate meter and the equations published by L'Huillier \& Thomson (1988) to convert meter readings to herbage mass. Assessments of pasture quality were made from one paddock on each of 4 farms within each catchment, with herbage samples collected from paddocks that were just about to be grazed by hand plucking 10 sub-samples to represent pasture selected by grazing cows. Collected samples of mixed herbage underwent NIR analysis for providing estimates of pasture protein, digestibility, metabolisable energy (ME), acid-detergent fibre (ADF), neutral-detergent fibre (NDF), soluble carbohydrate and dietary cation-anion difference (DCAD) levels.

\section{Results and discussion}

\section{Pasture growth rates and quality}

Monthly pasture growth rates and ME values, averaged across the first two years of measurement, are shown in Figures 2 and 3, respectively. Contrasting patterns of pasture growth and quality were evident between catchments. Relatively steep pasture growth profiles during spring and autumn were observed in the South Island catchments (Figure 2c,d) whereas the North Island catchments (Figure 2a,b) had a slightly more even growth profile throughout the year. This was evident by the greater winter and lower spring flush of growth in the North Island catchments. Conversely, pasture ME values were relatively consistent for the South Island catchments and generally ranged between 11 and $12 \mathrm{MJME} / \mathrm{kg} \mathrm{DM}$. In contrast, pasture ME values in the North Island catchments ranged between 9 and 12.2 MJME/kg DM, with a pronounced decrease evident for pasture samplings made in summer. This seasonal trend in pasture quality is consistent with findings by Litherland et al. (2002) and Moller et al. (1996). The data shown in Figure 2 provided the key inputs to the UDDER modelling exercise described below. For consistency, it was assumed that pasture growth rates and the level of management skill on low-, medium- and high-input farms within each catchment were identical. When measured pasture growth rates for the Toenepi catchment were run through the UDDER model a discrepancy became apparent in that measured values appeared to overestimate actual pasture growth, based on surveyed per cow and per ha farm performance data. Accordingly, monthly pasture growth rates in this catchment were normalised to match the observed seasonal pattern of pasture growth and farm milksolids production.

\section{Environmental emissions and energy consumption}

For each model farm system, the energy consumption and emissions of greenhouse gases (GHGs) and nitrate$\mathrm{N}$ losses in drainage waters were evaluated using the OVERSEER $^{\mathrm{TM}}$ Nutrient Budgets model. Because OVERSEER $^{\text {TM }}$ operates at a farm level, energy consumption and emissions were also determined for the off-farm dairying components such as supplement provision and winter grazing in the case of the 2 South Island catchments. This data was then aggregated with the whole-farm estimates derived from OVERSEER ${ }^{\mathrm{TM}}$, and expressed on a per unit land area basis (Figure 4). To allow comparison with indicators of farm economic performance, EBIT values, calculated at a $\$ 4$ payout, are also included.

It is clear from Figure 4 that both $\mathrm{N}$ and GHG emissions and energy consumption were consistently greater for high- compared to medium-input systems, and in turn for medium- compared to low-input systems. As noted for EBIT values, this pattern was evident when emissions and energy use were considered on a per tonne of milksolids basis (data not presented). Nitrate-nitrogen leaching losses from low input farms were greatest from the free-draining and shallow Eyre soils within the Waikakahi catchment, and least from the poorly-drained Pukemutu soils in the Bog Burn catchment, where the introduction of a high-input system was predicted to increasing $\mathrm{N}$ leaching losses by $60 \%$ or $12 \mathrm{~kg} \mathrm{~N} / \mathrm{ha} /$ year (Figure 4). In contrast, shifting from a low- to a highinput system within the Waiokura catchment increased $\mathrm{N}$ leaching losses approx. 2.5-fold, due to a combination of the much greater inputs of fertiliser $\mathrm{N}$ and maize silage and increased stocking rate. Previous research has identified that increased $\mathrm{N}$ losses from $\mathrm{N}$-fertilised farming systems are mostly attributable to the greater amounts of excretal $\mathrm{N}$ deposited on pastures, as a result of greater pasture production and animal stocking rate, rather than from direct losses of applied fertiliser N (Di \& Cameron 2002a,b; Ledgard et al. 1999, 2000; Monaghan et al. 2000; Silva et al. 1999). Considered at a whole system level, the inclusion of maize or cereal silage in the feeding regime also made a significant contribution to $\mathrm{N}$ leaching losses due to the relatively 
Figure 5 Greenhouse gas emissions (t $\mathrm{CO}_{2}$ equivalents/ha/year) for low-input (LI) and high-input (HI) dairy farming systems within the Toenepi, Waiokura, Waikakahi and Bog Burn catchments.

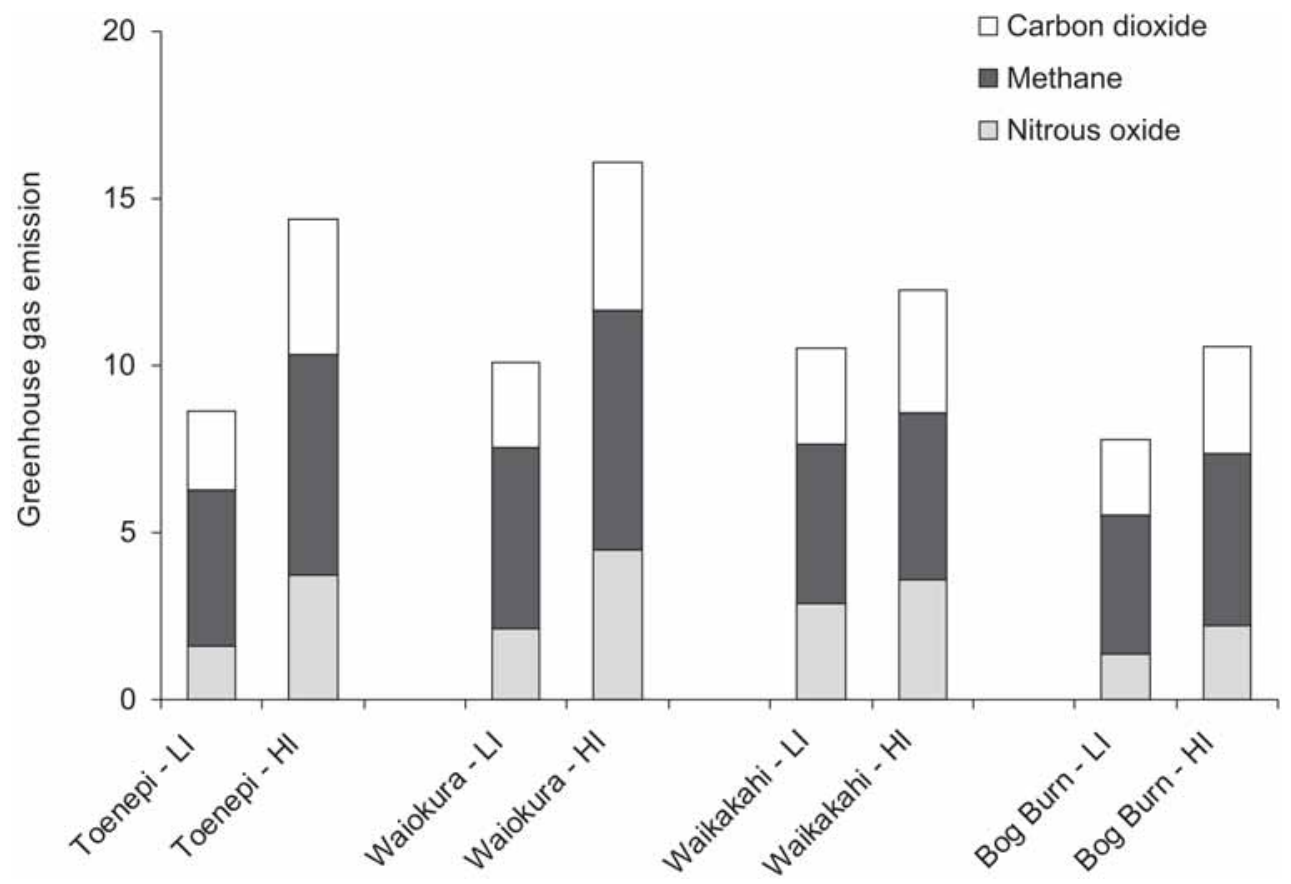

large amounts of $\mathrm{N}$ leaching estimated to occur following soil cultivation and crop establishment $(2.1 \mathrm{~kg} \mathrm{~N}$ leached per tonne of crop).

Emissions of greenhouse gases followed a broadly similar trend to that observed for $\mathrm{N}$ leaching losses, with the lowest emissions noted for low-input systems compared to medium- and high-input. The largest emissions were noted for high-input systems within the Toenepi and Waiokura catchments. Shifting from a lowto a high-input system increased farm GHG emissions by approx. 67, 60, 17 and 36\% within the Toenepi, Waiokura, Waikakahi and Bog Burn catchments, respectively (Figure 5). The relatively small difference between the GHG emissions in the low and high input systems in the Waikakahi catchment is due to the fact that inputs in the former are relatively high and similar to the medium-input system (see Methodology). The proportional contributions from methane, nitrous oxide and carbon dioxide (including capital and processing emissions) were broadly similar between catchments and between input systems, reflecting how intensification affected the whole system rather than one particular component of it such as animal methane emissions, i.e. more cows, more feed and more nitrogen cycling through the pastures leads to higher animal methane emissions, greater energy requirements for growing and handling additional feed (and processing of milk product) and greater nitrous oxide emissions from soil. Similarly, the lower GHG emissions in the Bog Burn catchment (Figure 5) are a reflection of the lower intensity of farming in this catchment due to lower inputs of $\mathrm{N}$ fertiliser and imported feeds (Table 2).

Energy use for each farm input system was relatively similar between catchments, ranging from 20 - 30, 26 36 , and 34 - $48 \mathrm{GJ} / \mathrm{ha} /$ year within the low-, medium- and high-inputs systems, respectively.

\section{Profitability}

We caution that our UDDER modelling and financial analyses pertain to 'average' low-, medium- or high-input model dairy systems. Within each of these groups, some farms will have greater or lesser profitability than the 'average' farm depending on factors that are particular to their situation, e.g. their ability to source cheaper feed, pasture management skills, etc. Despite this, our analyses have highlighted a number of interesting features. Evaluated on a per hectare basis (Figure 6), it would appear that:

- Excluding farms within the Waikakahi catchment, the economic performances of low- and medium-input farms were quite similar, with medium-input farms almost always slightly more profitable than low-input farms.

- The medium-input farms were generally the most profitable in the Toenepi and Bog Burn catchments, and in the Waiokura catchment at payouts of $\$ 3.50 / \mathrm{kgMS}$ or less. 
Figure 6 Per hectare EBIT values estimated for model low- $(\bullet)$, medium- $(\bigcirc)$ and high- $(\boldsymbol{\nabla})$ input dairy farms within the (A) Toenepi, (B) Waiokura, (C) Waikakahi, and (D) Bog Burn catchments at different MS returns.
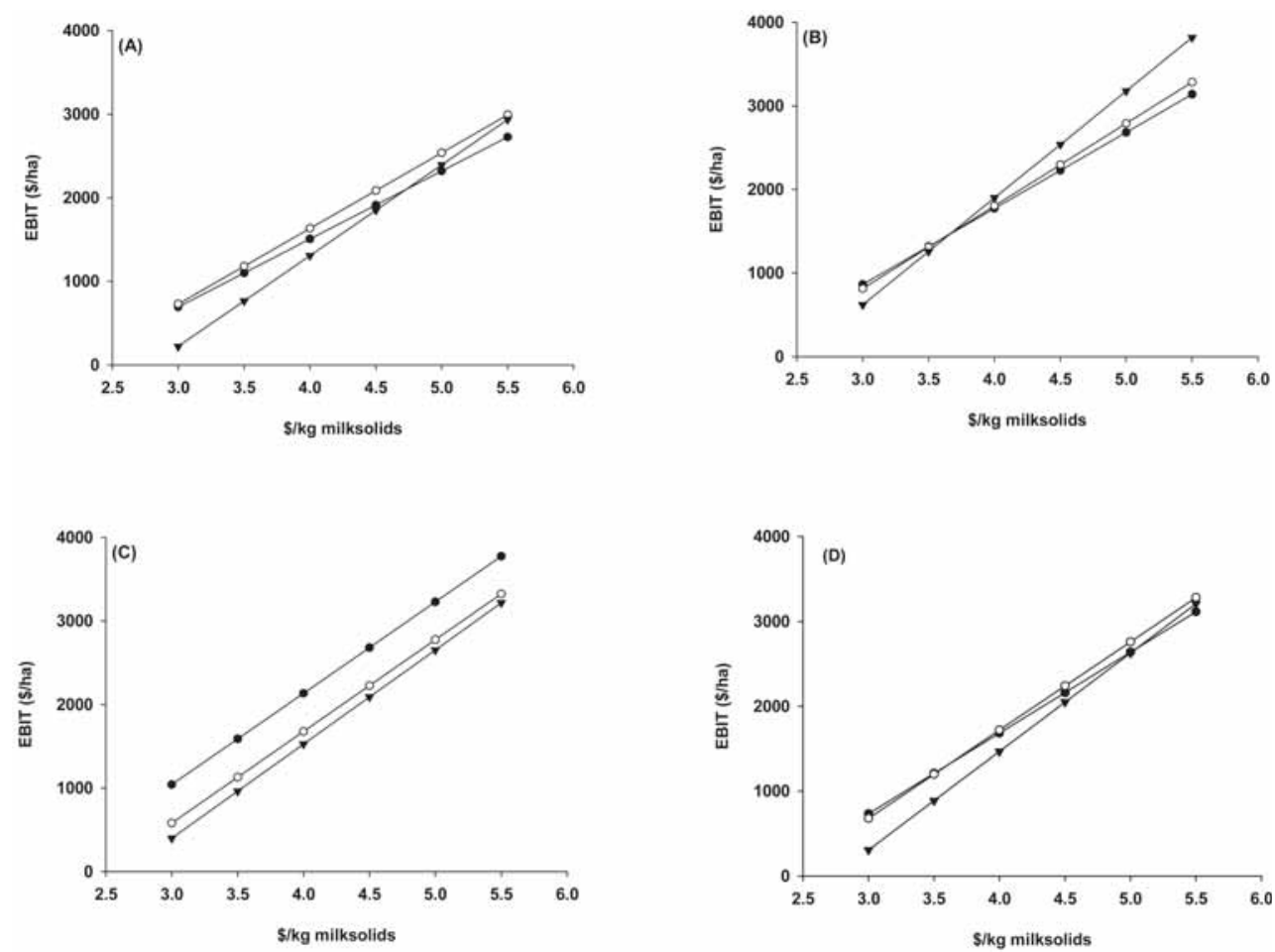

- High input farms were generally the least profitable system in the Waikakahi and Bog Burn catchments, and in the Toenepi and Waiokura catchments at payouts of less than $\$ 5$ and $\$ 4$, respectively.

With the exception of farms within the Waikakahi catchment, at payouts of between $\$ 4$ and $\$ 4.50$ there was surprisingly little difference in Earnings Before Interest and Tax (EBIT) between the low-, medium- and high-input systems, with less than $\$ 350$ separating the least and most profitable EBIT values.

When evaluated on a per tonne of milksolids (MS) basis, EBIT values were progressively (and consistently) reduced as farm intensity increased from a low- to a medium- and then to a high-input system (Figure 7). With the exception of farms within the Waikakahi catchment, there was relatively little difference in EBIT values between the low- and medium-input farm systems, but EBIT values for the high-input systems were significantly lower. The data in Figure 7 illustrate how milk production becomes more expensive as the farm system intensifies, although it should be noted that using EBIT as an indicator of farm financial performance does not factor in the cost of having land available for grazing animals. Similarly, this indicator does not factor in the capital costs associated with having additional infrastructure such as enlarged feeding pads required in many high-input dairy systems.

The economic indicators reported in Figures 6 and 7, whilst subject to the limitations of averaging farm data at a regional level, do highlight a couple of important features. When evaluated on a per tonne of MS basis, we note that EBIT was consistently reduced for high input farms because costs per $\mathrm{kg}$ MS increased with intensification. This finding is consistent with data reported in the literature (e.g. Silva et al. 2004; Macdonald 1999). When evaluated on a per hectare basis, however, the picture is less consistent, with intensification sometimes giving an increase in profitability (e.g. Waiokura catchment at payouts greater than $\$ 3.50 / \mathrm{kg}$ MS). We note that evidence in the literature also presents an inconsistent picture, with some analyses indicating increased (Deane 1999; Miller \& Blackwell 2000; Roche \& Reid 2002) or decreased (Macdonald 1999; Tayles \& Cottier 2002) business profitability with increasing intensification, whilst others suggest little change (Silva et al. 2004).

\section{Implications}

Our modelling analysis indicates that environmental emissions increased with increasing dairy farming 
Figure 7 EBIT values estimated for model low- $(\bullet)$, medium- $(O)$ and high- $(\boldsymbol{\nabla})$ input dairy farms within the $(A)$ Toenepi, (B) Waiokura, (C) Waikakahi, and (D) Bog Burn catchments at different MS returns.
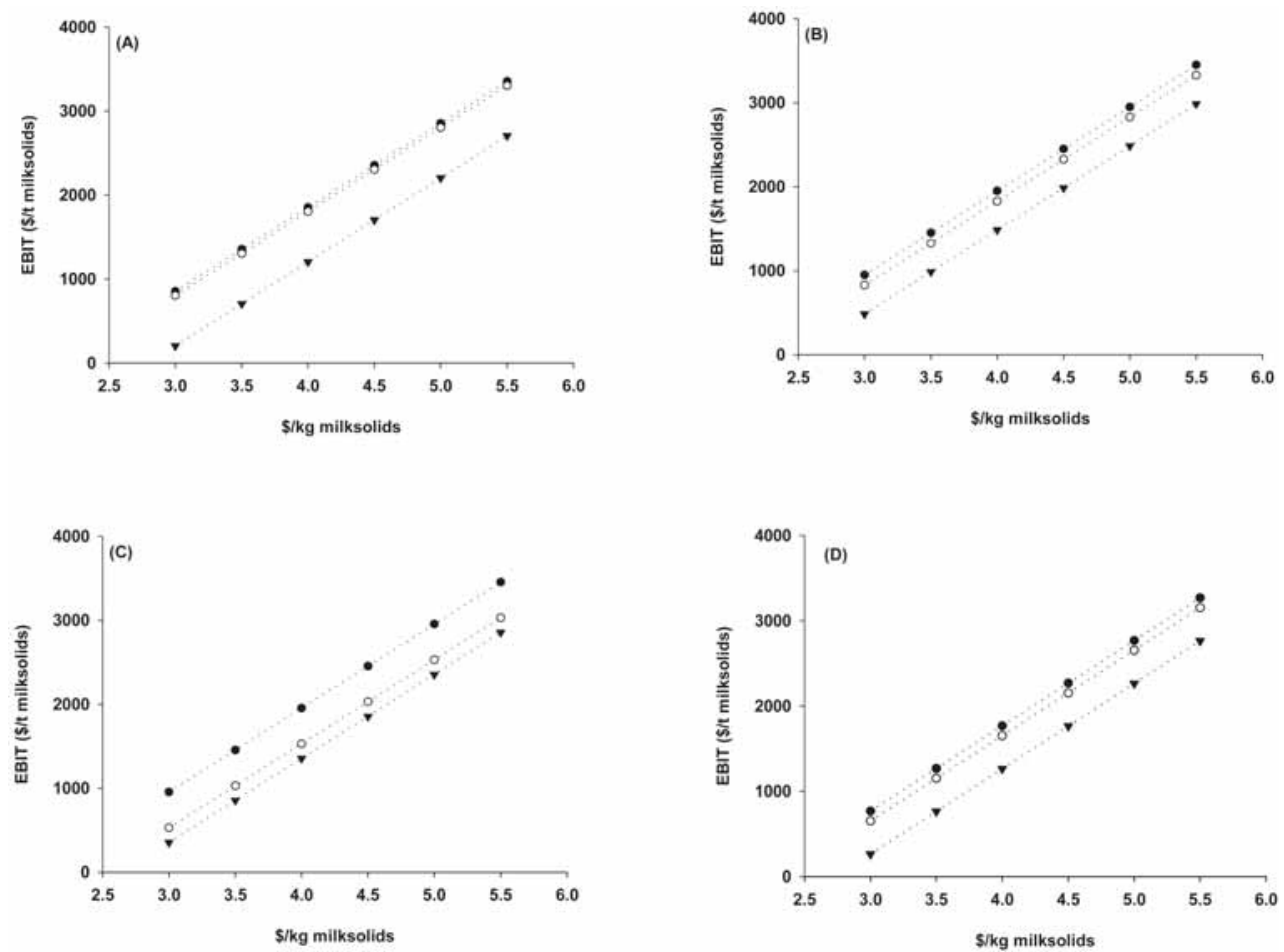

Figure 8 Modelled $\mathrm{N}$ leaching losses from the medium-input dairy system.

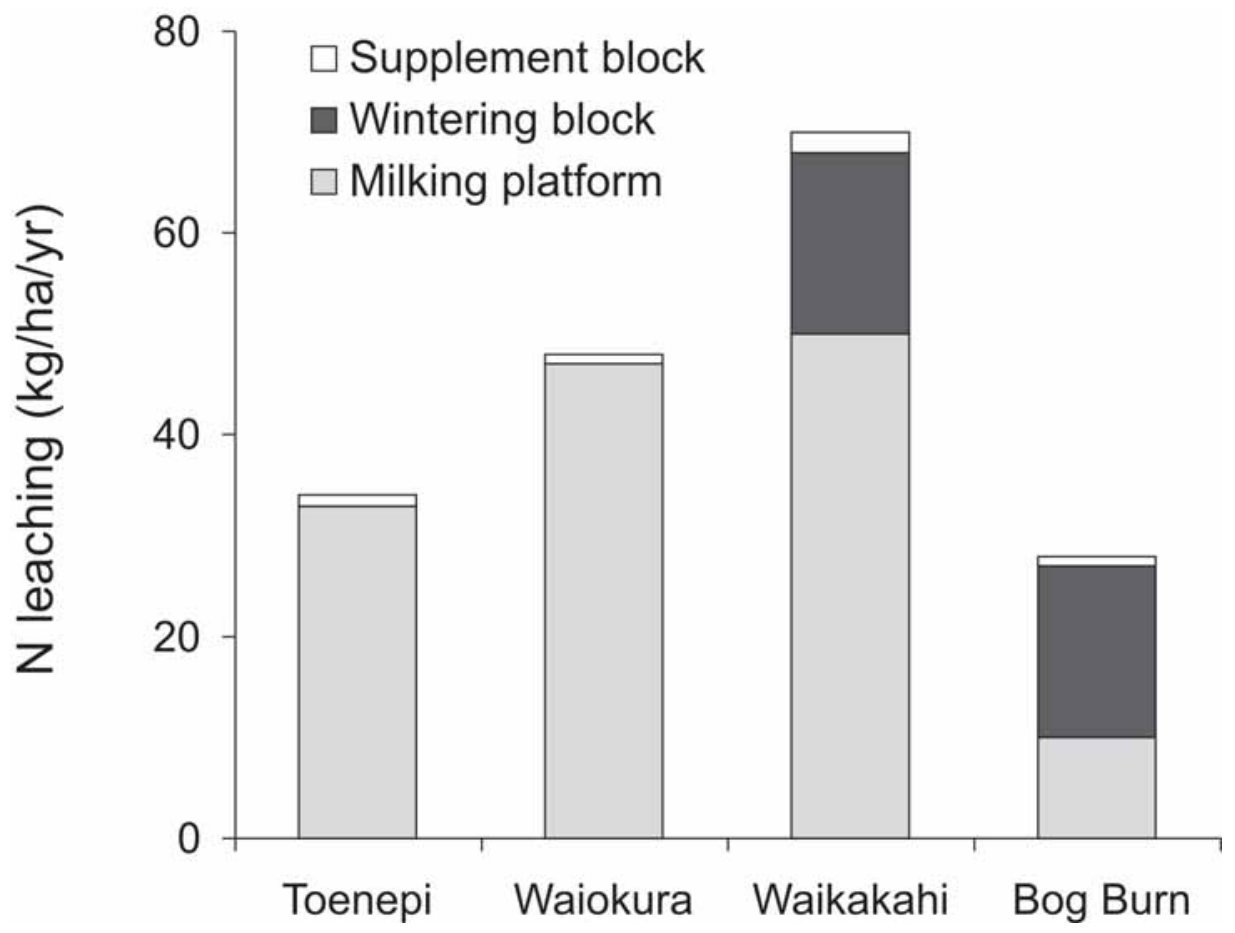


intensity within the four catchments. This environmental 'cost' for high-input systems was not compensated for by an increase in economic benefit unless the payout for milk increased above $\$ 3.50 / \mathrm{kg}$ MS for farms in the Waiokura catchment, or above $\$ 5.50 / \mathrm{kg}$ MS in the Toenepi and Bog Burn catchments. We do again caution that our analyses pertain to 'average' low-, medium- or high-input model dairy systems. Within each of these groups, some farms will have greater or lesser profitability than the 'average' farm. However, based upon typical costs for locally-available feed, grazing and fertiliser nutrients, we suggest that these average figures are representative of farming systems within their respective catchments. Some guidance to where greater system efficiencies can be achieved can be seen when the component contributions to $\mathrm{N}$ leaching are looked at individually for the medium-input farming system (Figure 8 ). The wintering part of the dairy system made a disproportionately large contribution to $\mathrm{N}$ losses within the 2 South Island catchments, providing 25 and $60 \%$ of the total whole-farm $\mathrm{N}$ leaching emission for the Waikakahi and Bog Burn catchments, respectively, despite representing only $15 \%$ of the whole dairy system area. The greater losses from the wintering part of the system arise due to (i) relatively large amounts of mineral $\mathrm{N}$ remaining in the soil in late autumn following pasture cultivation and forage crop establishment the preceding spring, and (ii) the deposition of much excretal $\mathrm{N}$ onto the grazed forage crop during winter when plant uptake is correspondingly low. It would therefore seem prudent that policy and managements which seek to reduce $\mathrm{N}$ emissions from dairy farms within these catchments should target the wintering part of the dairy operation in the first instance, given that low-emission wintering systems such as confined feedpad operations are currently available and used by some dairy farmers. An evaluation of the environmental and economic implications of such restricted grazing systems has been documented by de Klein \& Ledgard (2001) and Chadwick et al. (2002). Concomitant with these modified systems is the provision of additional effluent handling and storage facilities to ensure that effluent is retained on-farm and re-used when soil conditions and temperatures allow.

\section{ACKNOWLEDGEMENTS}

The research team would like to acknowledge the New Zealand Fertiliser Manufacturers Research Association for their financial support of this work. Dairy Insight funding was also used to complete the soil and farm surveys. Expert field and laboratory assistance from Alec McGowan, Chris Roach, Anita Souness and Dennis Enright is also gratefully acknowledged, as is the cooperation and constructive feedback provided from dairy farmers within each of the catchments.

\section{REFERENCES}

Chadwick, D.R.; Ledgard, S.F.; Brown, L. 2002. Nitrogen flows and losses in dairy farms in New Zealand and the UK: effects of grazing management. In: Dairy Farm Soil Management. (Eds L D Currie and P Loganathan). Occasional report No. 15. Fertiliser and Lime Research Centre, Massey University, Palmerston North. pp 319-332.

Davis, K.L.; Thomson, N. A.; McLean, N. R.; McCallum, D. A.; Hainsworth, R. J.; Wards, A. J.; Barton, R. G. 1999. Pasture growth on dairy farms in the Golden Bay and West Coast of the South Island. Proceedings of the New Zealand Grassland Association 60: 9-14.

De Klein, C.A.M.; Ledgard, S.F. 2001. An analysis of environmental and economic implications of nil and restricted grazing systems designed to reduce nitrate leaching from New Zealand dairy farms. I. Nitrogen losses. New Zealand Journal of Agricultural Research 44: 201-215

De Klein, C.A.M.; Ledgard, S.F.; Clark, H. 2002. Evaluation of two potential on-farm measures for reducing greenhouse gas emissions from an average dairy farm on the West Coast of the South Island of New Zealand. Proceedings of the New Zealand Grassland Association 64: 159-165.

Deane, T. 1999. The profitable use of supplementary feeds in pasture based dairy farm systems. Proceedings of the Ruakura Dairy Farmers' Conference 51: 64-77.

Dexcel 2003. Economic survey of New Zealand dairy farmers 2001-2002. 40pp.

Di, H. J.; Cameron, K. C. 2002a. The use of a nitrification inhibitor, dicyandiamide (DCD), to decrease nitrate leaching and nitrous oxide emissions in a simulated grazed and irrigated grassland. Soil Use and Management 18: 395-403.

Di, H. J.; Cameron, K. C. 2002b. Nitrate leaching and pasture production from different nitrogen sources on a shallow stoney soil under flood-irrigated dairy pasture. Australian Journal of Soil Research 40: 317334.

Larcombe, M.T. 1999. UDDER for Windows: A Desktop Dairyfarm for Extension and Research - Operating Manual. Maffra Herd Improvement Co-op, Maffra, Victoria.

Ledgard, S. F.; Penno, J. W.; Sprosen, M. S. 1999. Nitrogen inputs and losses from grass/clover pastures grazed by dairy cows, as affected by nitrogen fertilizer application. Journal of Agricultural Science 132: 215225.

Ledgard, S. F.; De Klein, C. A. M.; Crush, J. R.; Thorrold, B. S. 2000. Dairy farming, nitrogen losses and nitrate sensitive areas. New Zealand Society of Animal Production 60: 256-260. 
Litherland, A.J.; Woodward, S.J.R.; Stevens, D.R.; McDougal, D.B.; Boom, C.J.; Knight, T.L.; Lambert, M.G. 2002. Seasonal variations in pasture quality on New Zealand sheep and beef farms. Proceedings of the New Zealand Society of Animal Production 62: 138-142.

L'Huillier, P.J.; Thomson, N.A. 1988. Estimation of herbage dry mass in ryegrass-white clover dairy pastures. Proceedings of the New Zealand Grassland Association 49: 117-122.

Lynch, P.B. 1966. Conduct of Field Experiments. Bulletin No. 399. NZ Dept of Agric. pp.71-85.

MacDonald, K. 1999. Determining how to make inputs increase your Economic Farm Surplus. Proceedings of the Ruakura Dairy Farmers' Conference 51: 7887.

Miller, D.; Blackwell, M. 2000. Intensifying or expanding the farm business. Proceedings of the South Island Dairy Event, Invercargill: 88-92.

Ministry of Agriculture and Forestry, 2003. Dairy Monitoring Report http://www.maf.govt.nz/mafnet/ rural-nz/statistics-and-forecasts/farm-monitoring/ index.htm

Moller, S.N.; Parker, W.J.; Edwards, N.J. 1996. Withinyear variation in pasture quality has implications for dairy cow nutrition. Proceedings of the New Zealand Grassland Association 57: 173-177.

Monaghan, R.M.; Paton, R.J.; Smith, L.C.; Binet, C.
2000. Nutrient losses in drainage and surface runoff from a cattle-grazed pasture in Southland. Proceedings of the New Zealand Grassland Association 62: 99104

Roche, J.; Reid, A. 2002. High input dairy farming - the road to a better life, more money and more options. Proceedings of the South Island Dairy Event, Invercargill: 112-131.

Silva, R. G.; Cameron, K. C.; Di, H. J.; Hendry, T. 1999. A lysimeter study of the impact of cow urine, dairy shed effluent, and nitrogen fertiliser on nitrate leaching. Australian Journal of Soil Research 37: 357-369.

Silva, D.; Holmes, C.; Shadbolt, N.; Lopez-Villalobos, N.; Prewer, W.; Glassey, C.; Blackwell, M. 2004. High or low feed input farms: a picture of their productivity and profitability. Dairy Exporter: 78-79.

Tayles, G.; Cottier, R. 2002. Project analysis - allocation of capital. Proceedings of the South Island Dairy Event, Invercargill: 83-93.

Wells, C. 2001. Total energy indicators of agricultural sustainability: Dairy farming case study. Report to MAF. 79 pp.

Wheeler, D.M.; Ledgard, S.F.; de Klein, C.A.M.; Monaghan, R.M.; Carey, P.L.; McDowell, R.W.; Johns, K.L. 2003. OVERSEER ${ }^{\mathrm{TM}}$ nutrient budgets moving towards on-farm resource accounting. Proceedings of the New Zealand Grassland Association 65: 191-194. 
